\title{
The Influence of the Direction of Wood Cutting on the Vibration and Noise of Chainsaws
}

\author{
Wojciech RUKAT*, Bartosz JAKUBEK, Roman BARCZEWSKI, Mateusz WRÓBEL
}

\begin{abstract}
Chainsaws generate high levels of vibrations and noise during work. Regardless of the type of their drive (electric, combustion) chainsaws excel TLVs (Threshold Limited Values) of vibration accelerations and the A-weighted sound level specified for eight-hour working day. The intensity of a vibro-acoustic impact of chainsaws on their operators depends on many factors. One of them is the type of the drive. This is due to significant differences in chainsaw design (inter alia characteristics of the drive, rotational speed, quasi-constant for an electric drive and variable for a combustion one). For chainsaws of the same or alike power and different type of the drive levels of vibrations and noise may vary. In this article noise levels and frequency weighted vibration accelerations for different direction of cutting kerf have been compared. Tests were performed with the same interchangeable cutting set (guide bar, cutting chain). The repeatability of conditions of the cutting process was ensured.
\end{abstract}

Keywords: chainsaw; cutting direction; noise; vibration

\section{INTRODUCTION}

The mechanization of wood harvesting works has positive effects, such as increasing productivity and reducing the physical burden on users of chainsaws. On the other hand, it increases the risks associated with limb injuries, vibrations and noise, and increases the psychological burden on operators $[1,2]$.

Chainsaws, due to their relatively low operating costs and the possibility of working in hard-to-reach terrain, are the basic tool for obtaining and pre-processing of wood material [3]. The process of obtaining wood as a semifinished product for further processing is connected with the necessity to perform three basic procedures. These are: felling, limbing and cross-cutting, which are usually accompanied by auxiliary works [4]. The temporal share of these procedures is different and depends on the type of terrain (mountainous/low-lying) [5] and the applied logging method (manual, manual and by machinery, by machinery) $[6,7]$.

The vibration load of the operator, the technological forces transferred to the handles and the efficiency of the machining process depend on many factors. Because of their origin, these factors may be related to:

- device (drive type, technical condition, etc.) [8-12],

- tool (cutting set-guide bar and chain, guide bar length, pitch) [13-22]

- $\quad$ workpiece material (wood species, moisture) [23-27],

- individual characteristics of the operator (age, body structure, experience) [28].

In addition to vibration and noise, saw operators are also exposed to other harmful influences, such as:

- chemical-exhaust fumes, fuel mixture and lubricant for the guide bar [29-34],

- biological-molds, fungi, zoonoses [35-38],

- physical-dust generated during operation [34, 39].

Depending on the operations during forest work, a device with appropriate power is usually selected. Felling and cross-cutting operations are generally performed with chainsaws with power of over $2.5 \mathrm{~kW}$ [14]. On the other hand, limbing as well as auxiliary works are carried out with devices of lower power, e.g. $1.5 \mathrm{~kW}$. Such chainsaws are also used in the care of young stands (early and late thinning), in the work related with obtaining small-sized wood (trunk diameter up to $300 \mathrm{~mm}$ ) as well as in arboristics [25].

Moreover, depending on the type of work performed, the operator cuts the material at different angles to the longitudinal axis of the fibres (trunk axis). Due to the heterogeneity of the cellular structure of wood [40,41], the anisotropy of its mechanical properties [42], and the possibility of internal defects (knots, foreign bodiesbullets, hunting shot, nails, etc.) [43], the directionality of the cutting kerf may affect both the values of vibration acceleration of the device handles and the noise emitted by the saws. In the case of typical forestry work, cuts are usually made across the fibres. On the other hand, saw operators regularly make cuts both along and across the fibres of wooden elements during the construction of wooden buildings, roofing or carpentry work. In this case, when determining the actual vibration impact of the device on the operator, the differences in the vibration acceleration values of the saw handles resulting from the direction of wood cutting may be significant.

The aim of this paper is the determination of the influence of directionality of wood cutting in relation to the fibre axis (cross-cutting and ripping) on the emitted noise and vibration of chain saw handles. Comparative tests were carried out for chainsaws with combustion and electric drives.

\section{TESTING METHODOLOGY}

Measurements of vibration acceleration of saw handles were performed in accordance with ISO 7505:1986, ISO 22867:2011, EN ISO 5349-1, and EN ISO 5349-2 [44-47]. The measured parameters were frequency weighted (with correction characteristic $W_{h}$ ) instantaneous RMS values of vibration acceleration $-a_{h v I}$ recorded in three mutually perpendicular directions on chainsaw handles. Two triaxial piezoelectric acceleration transducers DYTRAN 3023M2 were used to record vibrations. The transducers were permanently attached to the handle of the device (see Fig. 1a and Fig. 1b).

Noise measurements were made in accordance with ISO 22868 [48]. The acoustic pressure was recorded with the ROGA RG-50 (ICP) free-field microphone mounted on a tripod. The position of the microphone relative to the operator's head is shown in Fig. 1c. The distance between 
the microphone and the operator's ear, which was more exposed to noise, was about $20 \mathrm{~cm}$. The microphone was placed on the right side of the body so that the operator's body would not be an acoustic obstacle to the sound emitted by the device. location of the vibration transducers
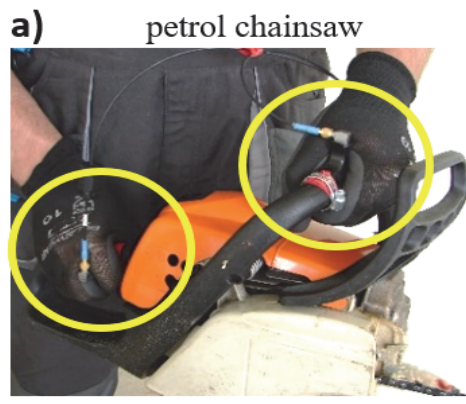

b) electric chainsaw

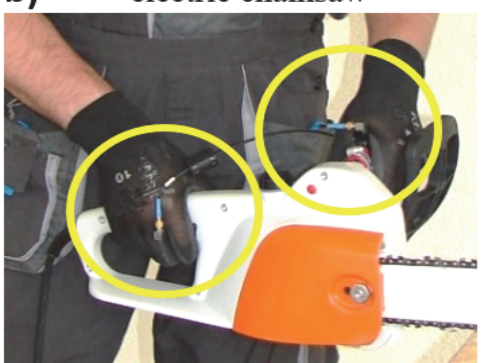

c) location of the measuring microphone

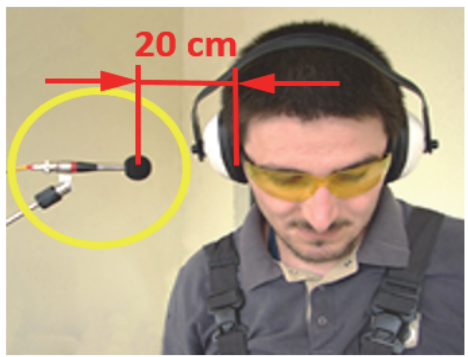

Figure 1 Location of vibration transducers $(a, b)$ and the measuring microphone (c) [15]

In order to guarantee a repeatable cutting technique, all tests were performed by one operator. It was a man with a body weight of $84 \mathrm{~kg}$ and a height of $174 \mathrm{~cm}$.
The operator's body position during measurements and a simplified diagram of the measurement path are shown in Fig. 2. a)

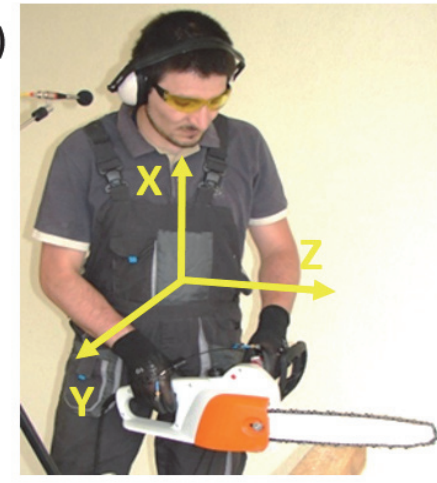

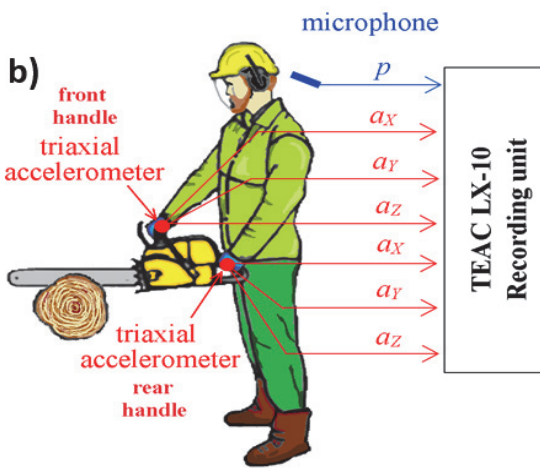

$\stackrel{\text { LAN }}{\rightarrow}$

PC with DASYLab

software; acquisition, processing, post-processing

\begin{tabular}{|c|}
\hline Measurement data: \\
FH $a_{h v}\left[\mathrm{~m} / \mathrm{s}^{2}\right] ;$ \\
RH $a_{h v}\left[\mathrm{~m} / \mathrm{s}^{2}\right] ;$ \\
$L_{\mathrm{p}}[\mathrm{dB}] \ldots$ \\
\hline
\end{tabular}

Figure 2 Body position of the operator (a) [15] and block diagram of the measurement path (b)

Calibration of the measurement path was carried out using the reference source of vibrations-K10 calibrator of RPT 97 - 146 type $\left(a_{c a l}=10 \mathrm{~m} / \mathrm{s}^{2}\right)$, and the reference sound source-KA-10 calibrator $\left(L_{P, c a l}=94 \mathrm{~dB}\right.$ for the frequency of $1000 \mathrm{~Hz}$ ). Calibration was carried out before and after the measurements.

Accelerometers and microphone cooperated with TEAC LX10 8 - channel digital signal recorder. Digital signal processing including parameterization of vibroacoustic (VA) signals was implemented in a dedicated application developed in a digital environment DASYLab (Data Acquisition System Laboratory). The signal sampling frequency was $48 \mathrm{kHz}$. The VA signals were recorded synchronously using signal sequencing (windowing) with a rectangular time window with a size of 4096 samples (about 1/12th of a second). This way of signal acquisition made it possible to conduct analyses in a short-time perspective and to determine the instantaneous values of parameters and characteristics of the vibration and acoustic signal.

The material treated was pine beams with a crosssection of $70 \times 90 \mathrm{~mm}$, in the air-dry state (moisture content in the material was $11 \pm 2 \%$ ). The research was conducted in two variants of cutting for each of the saws (electric and petrol). In the first variant, a cross-cut in the material without defects was made. In this case, the startup process, the idle phase-ID (about $2 \mathrm{~s}$, idle phase is not present in case of the electric saw), the phase of reaching the maximum speed without load-RA, the cutting phase consisting of a sequence of 9 cuts across the fibres (simulating the full load mode-FL) were recorded successively. For the second variant, the cutting sequence consisted of one rip-cut, parallel to the longer of the beam's edge dimensions. Sample beam cross-sections obtained during the measurements and graphic illustration of the successive test phases for both test variants (using the petrol saw) are presented in Fig. 3.

For the tests there were used saws (electric and petrol) of the leading brand on the market, with similar technical parameters. This made it possible to use the same cutting system (guide bar + chain). The same pre-tension of the saw chain was set each time. Technical data of chainsaws is presented in Tab. 1.The comparison of the influence of the cutting direction (cutting kerf) on handle vibrations and the noise emitted was carried out on the basis of fragments of registered signals, which correspond only to the cutting process (see Fig. 3). The signal fragments include 9 intersections for cross-cutting or one rip-cut. The considered (analysed) signal fragment therefore includes the cutting process in the FL mode and related transitional phases, which include: the entry of the blade into the material, and the exit of the blade therefrom. Intentionally, startup, idle speed-ID, and operation at maximum speed without load-RA preceding the first intersection were omitted. 
Cross-cutting

a)

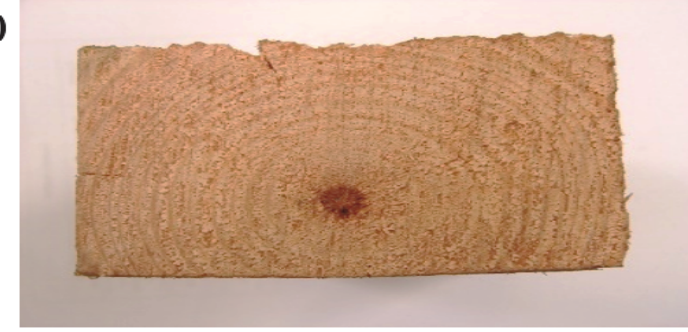

c)

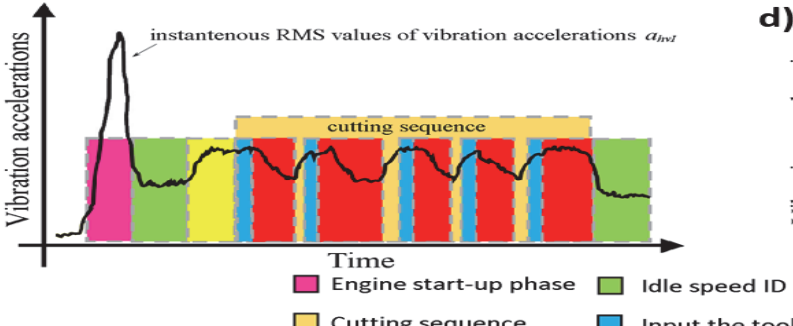

b)

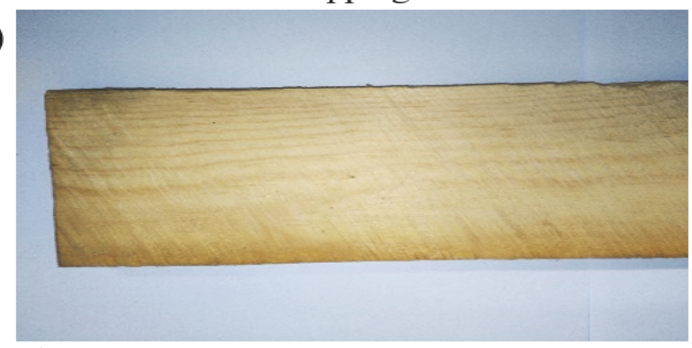

d)

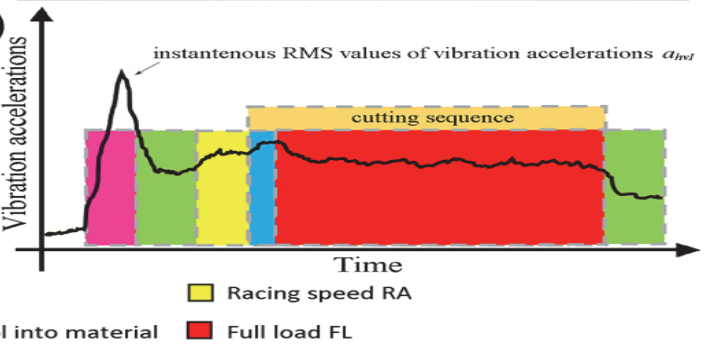

Figure 3 View of cross-sections of beams obtained by cross-cutting (a), and ripping (b), illustration of test phases applied to changes in instantaneous values of vibration accelerations (c), (d)

Table 1 Technical parameters of chainsaws used during research

\begin{tabular}{|c|c|c|}
\hline Drive type & Petrol & Electric (mains) \\
\hline Power / kW & 1.5 (at 10000 RPM) & 1.4 (at $7900 \mathrm{RPM}$ ) \\
\hline Maximum linear speed of the cutting chain $/ \mathrm{m} / \mathrm{s}$ & 24.8 & 14.6 \\
\hline Cutting chain pitch ("); the cutting chain used; type of cutting tooth & \multicolumn{2}{|c|}{ 3/8" P; 61 PMM3 (1.1 mm); semi-chisel } \\
\hline Guide bar length $/ \mathrm{cm}$ & 35 & 35 \\
\hline
\end{tabular}

\section{RESULTS OF VIBRATION MEASUREMENTS}

The influence of the direction of wood cutting on the vibrations of saws was determined on the basis of the comparison of RMS values of vibration accelerations of the handles measured during cutting. The results of vibration measurements of the rear handle of the tested saws are presented in a graphical form. Changes in the instantaneous values of vibration accelerations $a_{h v I}$ are shown in Fig. 4 and Fig. 5. These figures show a comparison of frequencyweighted (with correction characteristic $W_{h}$ ) instantaneous RMS values of vector sums of the $a_{h v I}$ vibration accelerations in the case of cross-cutting and ripping with a petrol chainsaw (Fig. 4) and an electric one (Fig. 5). The nature of the $a_{h v I}$ changes for the front handle is qualitatively similar and differs only in quantitative terms (see Tab. 2).

With an internal combustion saw, the highest instantaneous vibration acceleration values were recorded at the moment of starting the drive unit (two-stroke singlecylinder engine). This is due to the energetic jerk of the starter cord. After starting the engine, the device starts operating at idle speed (ID), approx. 2800 RPM. In this phase, the instantaneous values of vibration accelerations decrease and their stabilization takes place. Increasing the speed to a maximum value of approx. 13500 RPM without load causes an increase in the value of $a_{h v I}$. The local, lower maxima visible in Fig. 4 for cross-cutting are related to the successive intersections of the beam. They consist of alternating phases:

- the run-up of the cutting chain and the entry of the cutting edge into the material-accompanied by an increase in vibration acceleration,

- stabilization of the rotational speed for the cutting process (approx. $10000 \mathrm{RPM}$ ) and the transition to full load (FL) mode, where the vibration accelerations decrease,

- exit of the cutting set from the processed material, followed by a decrease in rotational speed due to releasing the gas handle and changing the position of the cutting set at idle speed,

- $\quad$ renewed speed up of the cutting chain and making another cut.

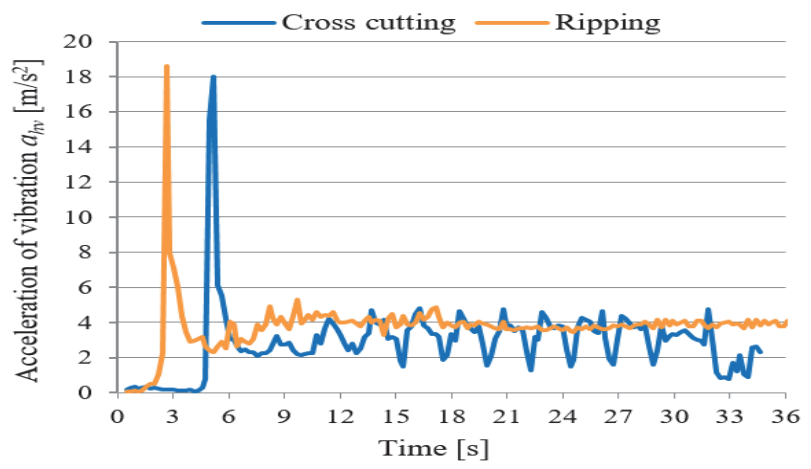

Figure 4 Comparison of the instantaneous RMS values of the vibration acceleration of the rear handle of a petrol saw during the cross-cutting and the ripping processes

In the case of cross-cutting, the $a_{h v I}$ values are highly variable. The instantaneous values range from approx. 1.9 to approx. $5 \mathrm{~m} / \mathrm{s}^{2}$. The average value for the entire cutting process is $3.55 \mathrm{~m} / \mathrm{s}^{2}$. Changes in the vibration acceleration values are closely related to the operating modes of the drive unit. On the other hand, vibrations in the case of ripping are characterized by lower variability of instantaneous values of vibration accelerations. However, in this case the values are higher and range from approximately $3.8 \mathrm{~m} / \mathrm{s}^{2}$ to approximately $5.5 \mathrm{~m} / \mathrm{s}^{2}$ and are, on average, $4.65 \mathrm{~m} / \mathrm{s}^{2}$. 
The instantaneous RMS values of the vibration accelerations recorded on the rear handle of the electric saw for the same variants (cross-cutting in a defect-free place and ripping) are shown in Fig. 5. As with the internal combustion saw, the instantaneous RMS values of the vector sums of vibration accelerations $a_{h v I}$ are shown in the figure.

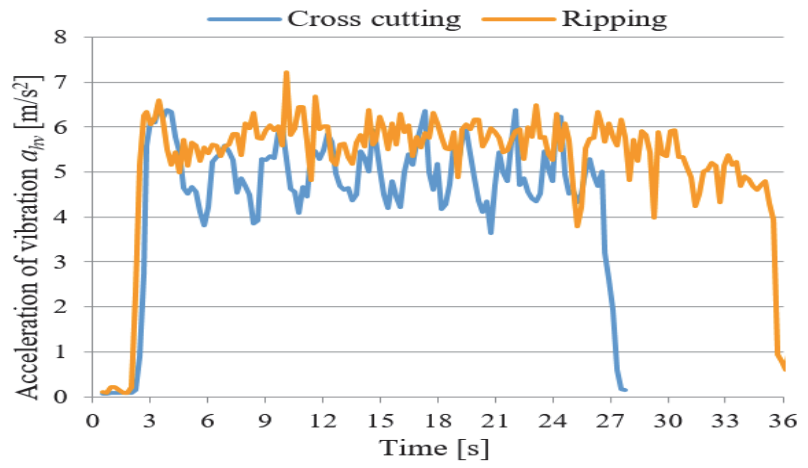

Figure 5 Comparison of the instantaneous RMS values of the vibration acceleration of the rear handle of an electric saw during the cross-cutting and the ripping processes

The nature of the vibration effects of the electric saw on the operator compared to the internal combustion saw in terms of instantaneous RMS values is qualitatively different. Due to the specificity and design of the drive system, the electric saw can only operate in two modesmaximum speed without load-RA approx. 7900 RPM, and full load FL.

Like in the case of the petrol chainsaw, a crosscut is made up of the following alternating phases: run-up, cutting and exit of the blade from the material. In contrast, the vibration acceleration values, unlike those of the internal combustion saw, reach their highest values when working without load. The recorded $a_{h v I}$ values are characterized by considerable variability over time. The instantaneous values range from approximately $3.6 \mathrm{~m} / \mathrm{s}^{2}$ to approximately $6.4 \mathrm{~m} / \mathrm{s}^{2}$ and average $5.06 \mathrm{~m} / \mathrm{s}^{2}$. Instantaneous vibration acceleration values for ripping are characterized by much greater variability. They range from approximately $3.8 \mathrm{~m} / \mathrm{s}^{2}$ to approximately $7.2 \mathrm{~m} / \mathrm{s}^{2}$ and amount to an average of $5.61 \mathrm{~m} / \mathrm{s}^{2}$.

Tab. 2 presents a comparison of the averaged RMS values of vibration accelerations corrected by $W_{h}$ characteristics, determined according to EN ISO 5349-1 and 5349-2 [46, 47], for individual directions of the reference system axes, and the implemented cutting variants.

Table 2 Summary of the results of measurements of vibration accelerations of the handles of the tested saws

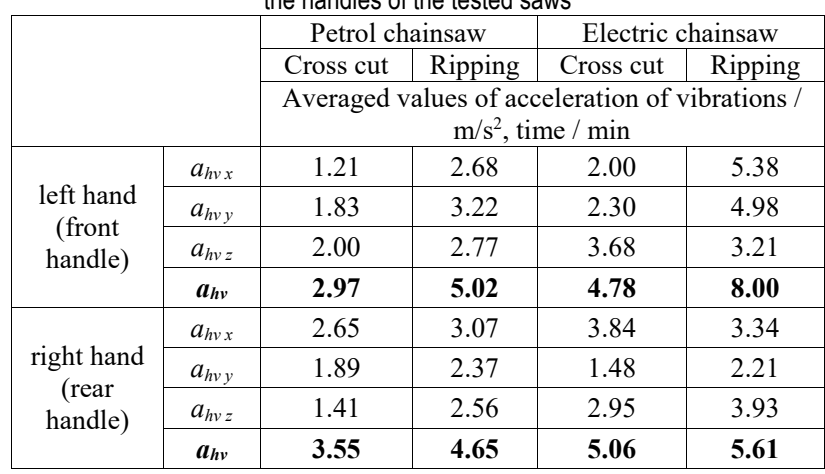

Higher acceleration values of vibrations of the petrol chainsaw handles were observed during ripping. These are $5.02 \mathrm{~m} / \mathrm{s}^{2}$ for the front and $4.56 \mathrm{~m} / \mathrm{s}^{2}$ for the rear handles. The vibration of the rear handle of an internal combustion saw has the highest vibration acceleration values in the $X$ axis direction (see Fig. 2a). Such regularity was observed both in the case of cross-cutting and ripping. The direction of the dominant vibration action on the front handle depends on the cutting variant (direction $Z$ for cross-cutting and $Y$ for ripping).

Higher averaged values of vibration acceleration $a_{h v}$ of the electric chainsaw, similarly as in the case of the petrol chainsaw, were observed during ripping. They are 8.00 $\mathrm{m} / \mathrm{s}^{2}$ for the front and $5.61 \mathrm{~m} / \mathrm{s}^{2}$ for the rear handles.

The results in Tab. 2 also show that the electric saw is more vibroactive, by approximately $46 \%$. The highest values of vibration acceleration $a_{h v}$ were recorded on the front handle during ripping (the dominant direction of interactions- $X$ see Fig. 2a). The dominant direction of vibrations of both handles of the electric saw depends on the cutting variant.

To sum up, regardless of the type of drive of the saw, a rip-cut compared to a cross-cut is accompanied by a more intense influence of local vibrations on the saw operator. This is due to the higher time share of the working phase (wood cutting).

\section{RESULTS OF ACOUSTIC PRESSURE MEASUREMENTS}

The analysis of the influence of cutting kerf direction on the noise generated by the saws was based on the comparison of sound levels $\mathrm{A}, L_{p \mathrm{~A}}$. The subsequent drawings show the course of changes in the instantaneous values of the corrected sound pressure level depending on the performed cutting variants for both chainsaws. The course of changes in the instantaneous values of sound pressure levels in octave bands with centre frequencies from $125 \mathrm{~Hz}$ to $16 \mathrm{kHz}$ show a high correlation coefficient with the course of changes of the sound pressure level corrected by filter A. Low-frequency noise is not strictly process dependent, as can be seen from the low correlation coefficient values for octave bands with centre frequencies of $31.5 \mathrm{~Hz}$ and $63 \mathrm{~Hz}$, which are not related to the operation of the equipment. The values of the linear correlation coefficients $R$ between the sound pressure levels in individual octaves and the A-weighted sound level are summarized in Tab. 3.

Due to the high degree of correlation between sound pressure levels in most octaves and the A-weighted sound level, and the lack of correlation between the levels in the lowest octaves and $L_{p \mathrm{~A}}$, only the A-weighted sound level measured during the tests was graphically presented.

The instantaneous A-weighted sound levels recorded for the two variants of cutting with the petrol chainsaw are shown in Fig. 6, and when working with the electric chainsaw-in Fig. 7. 
Table 3. Values of Pearson's linear correlation coefficient-R for individual cutting variants

\begin{tabular}{|c|c|c|c|c|c|c|c|c|c|c|c|c|}
\hline & & & \multicolumn{10}{|c|}{ center frequency of a band $f_{\mathrm{c}} / \mathrm{Hz}$} \\
\hline & & & 31.5 & 63 & 125 & 250 & 500 & 1000 & 2000 & 4000 & 8000 & 16000 \\
\hline \multirow{4}{*}{$\begin{array}{l}\text { The A } \\
\text { sound } \\
\text { level } L_{\mathrm{pA}}\end{array}$} & \multirow{2}{*}{$\begin{array}{c}\text { petrol } \\
\text { chainsaw }\end{array}$} & cross cut & 0.15 & 0.41 & 0.84 & 0.82 & 0.95 & 0.98 & 0.97 & 0.96 & 0.96 & 0.96 \\
\hline & & rip-cut & 0.13 & 0.33 & 0.81 & 0.75 & 0.87 & 0.94 & 0.98 & 0.97 & 0.97 & 0.97 \\
\hline & \multirow{2}{*}{$\begin{array}{l}\text { electric } \\
\text { chainsaw }\end{array}$} & cross cut & 0.14 & 0.01 & 0.62 & 0.81 & 0.92 & 0.93 & 0.98 & 0.98 & 0.97 & 0.96 \\
\hline & & rip-cut & 0.22 & 0.66 & 0.84 & 0.96 & 0.98 & 0.99 & 0.99 & 0.99 & 0.99 & 0.99 \\
\hline
\end{tabular}

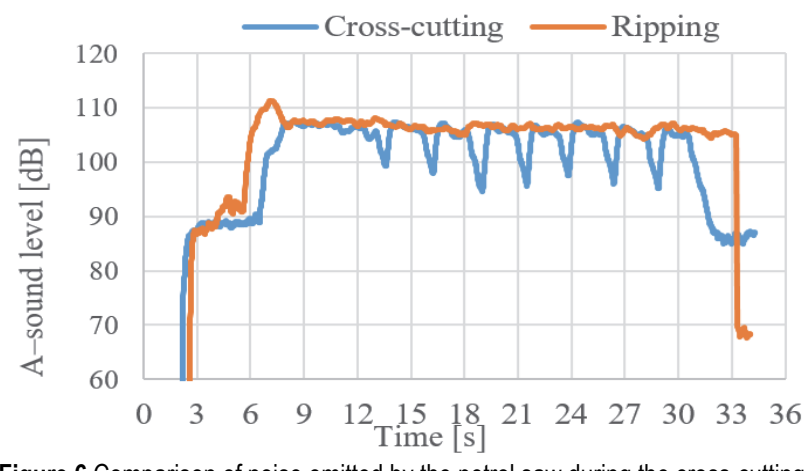

Figure 6 Comparison of noise emitted by the petrol saw during the cross-cutting and ripping processes

Fig. 7 shows the A-weighted sound levels recorded during operation of the electric saw. As in the case of the petrol saw, they were registered synchronously with the vibration signal presented in Fig. 5.

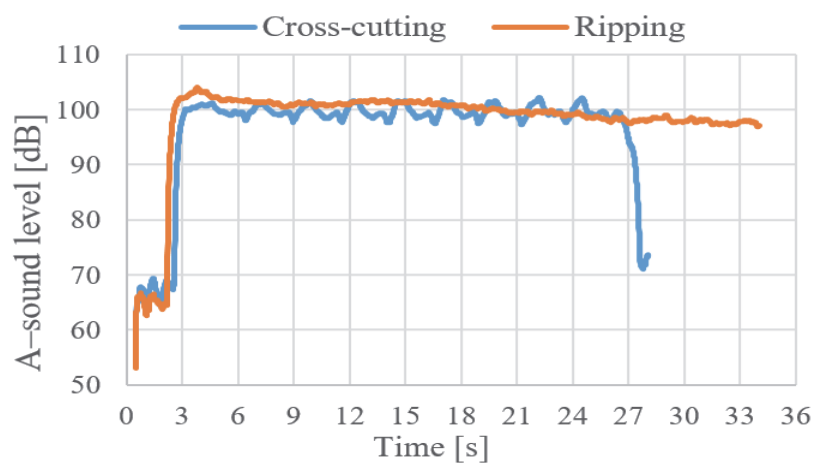

Figure 7 Comparison of noise emitted by the electric saw during the crosscutting and ripping processes

The analysis of the instantaneous A-weighted sound levels during the operation of the electric saw allows, for the variant of cross-cutting (similarly to the petrol saw), to distinguish the individual phases of the drive unit operation and determine their duration. Compared to the internal combustion saw, it is slightly more difficult to detect the operating phases of the electric saw by means of an acoustic signal. As with the petrol saw, the decreasing trend in the sound pressure level during ripping, which can be observed in Fig. 7, is caused by the distance between the machine and the measuring microphone.

Fig. 8 and Fig. 9 show the time-averaged values of sound pressure levels in octave bands, linear and Aweighted sound levels, for petrol and electric chainsaws and for individual cutting variants. Due to the low correlation between sound pressure levels in the $31.5 \mathrm{~Hz}$ and $63 \mathrm{~Hz}$ bands with the remaining levels, these results have not been presented in graphic form. The noise emitted by the petrol chainsaw is slightly different for the two cutting variants. The difference between the averaged linear sound pressure levels was $1.3 \mathrm{~dB}$. In the majority of octaves, higher pressure levels were observed for ripping. The differences in these levels are small. The largest of these was recorded in the octave with a center frequency of $125 \mathrm{~Hz}$, which contains the ignition frequency of the drive unit. It is possible that the differences shown in the figure are due to a higher load on the saw (variable length of the cutting line) in the case of cross-cutting. It is worth noting that the highest values of sound pressure levels were recorded in octaves, whose center frequencies coincide with the range of the highest sensitivity of human hearing. The average A-weighted sound level when cutting with the petrol chainsaw ranges between 105 and $106 \mathrm{~dB}$.

Regardless of the cutting variant, the average Aweighted sound level of the electric saw is approx. $100 \mathrm{~dB}$. However, there are significant differences in octaves with center frequencies of $125 \mathrm{~Hz}$ and $250 \mathrm{~Hz}$. This is due to changes in the load-dependent motor speed. For crosscutting, the rotational frequency changes in such a way that, during proper cutting of the material, it is contained in the octave with the center frequency of $125 \mathrm{~Hz}$, and during transition phases in the $250 \mathrm{~Hz}$ octave. As with the petrol chainsaw, the highest sound pressure levels were measured in the band of the highest sensitivity of human hearing.

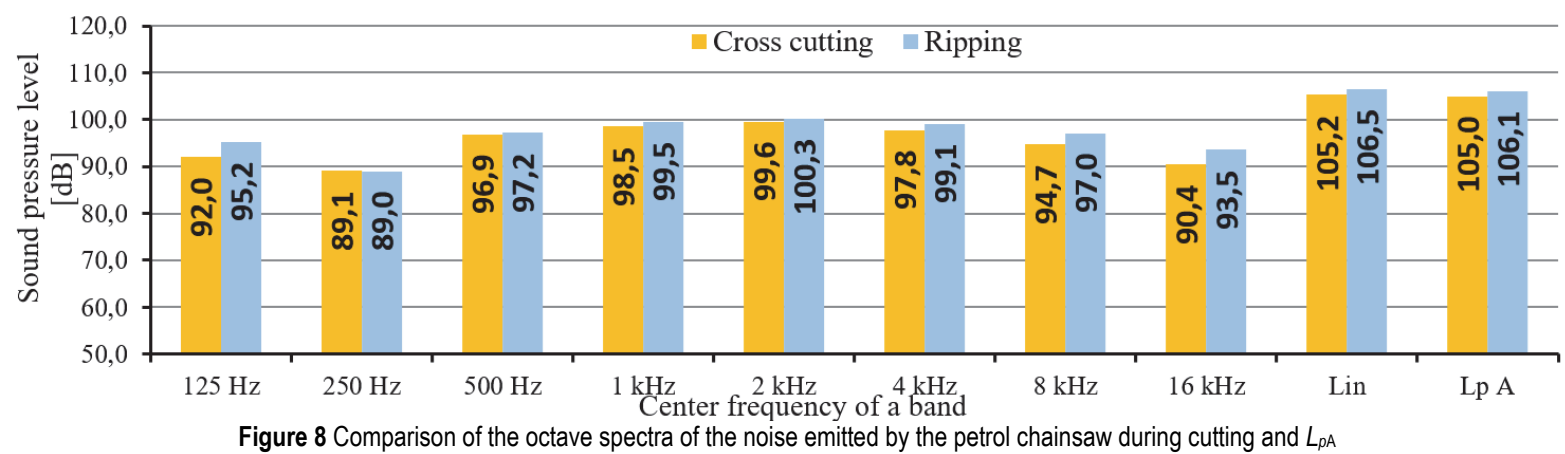




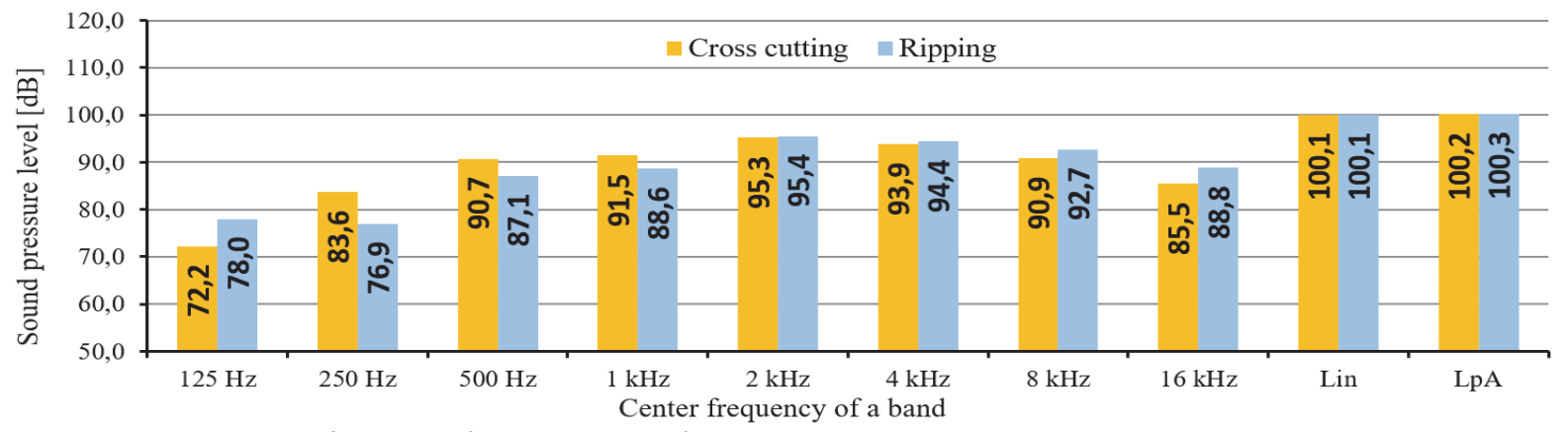

Figure 9 Comparison of the octave spectra of the noise emitted by the electric chainsaw during cutting and $L_{p \mathrm{~A}}$

\section{CONCLUSION}

The vibrations generated by chainsaws depend mainly on the drive unit loading. In the case of identical loads, the vibrations measured on the handles of an electric saw are greater than those recorded on a petrol saw. Moreover, in the case of the petrol chainsaw, the vibrations recorded when working at full load are greater than when working at maximum speed without load, the opposite is true for the electric saw.

Based on the results of vibration measurements, it was found that the acceleration of vibrations of saw handles depends on the direction of wood cutting. Both tested devices emit higher amplitude vibrations during ripping. For the petrol chainsaw, in the case of ripping, the increase of the $a_{h v}$ value compared to the cross-cutting was approx. $70 \%$ for the front handle and approx. 30\% for the rear handle. For the electric saw, the increase in the level of vibrations during ripping in relation to cross-cutting was $65 \%$ for the front handle and $10 \%$ for the rear handle. Such large differences are partly due to the fact that the crosscuts sequences are accompanied by transition phases: the entry of the blade into the material and exit there from. The applied measurement method consisting in taking into account only those fragments of the signal which correspond to the cutting process (full load) allows to state objectively that the vibrations of the petrol saw do not depend on the direction of wood cutting. On the other hand, the vibrations recorded on the handles of the electric saw depend on the direction of wood cutting and are higher during ripping.

The results of the A-weighted sound level measurements showed that both in the case of electric and petrol chainsaws the noise emitted by the equipment is practically independent of the direction of the cutting kerf. However, it depends on the type of drive unit of the saw. The A-weighted sound level of the electric chainsaw is approximately $5.5 \mathrm{~dB}$ lower than that of the petrol one. The noise emitted by both devices is the highest when they operate in the mode of maximum speed without loadracing. The sound pressure levels in the individual octave bands are correlated with each other, with the linear sound pressure level and with the A-weighted sound level. The exception is noise in the octave bands with center frequencies of $31.5 \mathrm{~Hz}$ and $63 \mathrm{~Hz}$, where no effect of the cutting process was observed. Furthermore, the highest sound pressure levels in all cases were measured in the band of the highest sensitivity of human hearing (2 - 4 $\mathrm{kHz}$ ).
In order to protect the operator's health, as well as to reduce the onerousness of VA impact, while working with low-power chainsaws, especially while ripping with an electric saw, it is advisable to use individual personal protective equipment: anti-vibration gloves and hearing protectors. The results of the research have shown that EAV and ELV may be exceeded in the case of improper work organization of low-power chainsaws. From the point of view of international regulations-Directive 2002/44/EC of the European Parliament and of the Council [49] the use of chainsaws in the manner described in the article will not lead to permanent damage to health. Although, it is necessary to bear in mind more restrictive, local regulations [34]. A negative impact on the operator's health can also be expected in the absence of personal protective equipment [50-53].

Comparing the detection capabilities of the vibration and acoustic signals in terms of identification of the operating states and load of the drive unit, the acoustic signal has significantly better detection characteristics, especially with regard to the petrol chainsaw.

\section{Acknowledgement}

The results presented are results of the research that was funded with grant 02/21/DSMK/3538/2018 for education allocated by the Ministry of Science and Higher Education of the Republic of Poland.

\section{REFERENCES}

[1] Axelsson, S. (1998). The Mechanization of Logging Operations in Sweden and its Effect on Occupational Safety and Health. Journal of Forest Engineering, 9(20), 25-31.

[2] Nowacka, W. Ł. (2012). Selected workload elements of the machine operators working in timber harvesting. Ergonomic point of viev. Acta Stientarum Polonorum, Silvarum Colendarum Ratio et Industria Lignaria, 11(3), 29-36.

[3] Sztyber, J. F. (2017). Tools and machines for major logging operations: authorized notes. Oficyna wydawnicza Politechniki Opolskiej, ISBN 836069133 (in Polish).

[4] Chojnicki, J. (2013). Safe logging-a guide.Państwowa Inspekcja Pracy, Gtówny Inspektorat Pracy; Warsaw (in Polish).

[5] Câmpu, V. R. \& Ciubotaru, A. (2017). Time consumption and productivity in manual tree felling with a chainsaw-a case study of resinous stands from mountainous areas. Silva Fenica, 52(2), 1-19. https://doi.org/10.14214/sf.1657

[6] Wójcik, K. (2007). Analysis of processing operation time and it's percent share in timber harvesting with the chain saws. Agricultural Engineering, 50, 71-77.

[7] Suchomel, J., Tajboš, J., \& Slančik, M. Analysis of work time consumption in the cutting the beeach using motor-manual 
method. $4^{\text {th }}$ International Scientific Conference: Woodworking Techniques, 540-548. Czech University of Life Sciences, Prague-Czech Republic, University ZagrebCroatia; ISBN 978-80-213-2182-3.

[8] Neri, F., Laschi, A., Foderi, C., Fabiano, F., Bertuzzi, L., \& Marchi, E. (2018). Determining Noise and Vibration Exposure in Conifer Cross-Cutting Operations by Using LiIon Batteries and Electric Chainsaws. Forests, 9(8:501), 113. https://doi.org/10.3390/f9080501

[9] Skarżyński, J. \& Wójcik, K. (2006). Analysis of influence of technical condition parameters of the petrol chainsaw and wood cutting on the magnitude of emitted vibrations. Acta Stientarum Polonorum, Silvarum Colendarum Ratio et Industria Lignaria, 5(1), 63-72.

[10] Rukat, W., Barczewski, R., Jakubek, B. M., \& Wróbel, M. (2018). The comparison of vibro-acoustic impact of chainsaw with electric and combustion drives. MATEC Web of Conferences, 182(02020), 1-7. https://doi.org/10.1051/matecconf/201818202020

[11] Colantoni, A., Mazzocchi, F., Cossio, F., Cecchini, M., Bedini, R., \& Monarca, D. (2016). Comparisons between Battery Chainsaws and Internal Combustion Engine Chainsaws: Performance and Safety. Contemporary Engineering Sciences, 9(27), 1315-1337. https://doi.org/10.12988/ces.2016.68133

[12] Wójcik, K. \& Kalinowski, T. (2018). The speed of blunting of saw chain cutting edges during cross-cutting. Annals of Warsaw University of Life Sciences-SGGW, Agriculture, 71, 51-59. https://doi.org/10.22630/AAFE.2018.71.6

[13] Wójcik, K. (2017). Vibrations produced by petrol chainsaws with variable-length guide bars during cross cutting. Annals of Warsaw University of Life Sciences-SGGW, Agriculture, 70, 37-47. https://doi.org/10.22630/AAFE.2017.70.16

[14] Wójcik, K. (2012). Influence of the size of chainsaw and lenght of the guide bar on vibrations emitted during delimbing. Nauka Przyroda Technologie, 6/2(24), 1-12 (in Polish).

[15] Wójcik, K. (2000). Effect of saw chain design on vibrations emitted by chain saws. Annals of Warsaw Agricultural University-SGGW, Agriculture, 36, 43-49.

[16] Maciak, A. (2015). The impact of initial tension on rapidity of dulling of saw cutting chains during cross-cutting of pine wood. Annals of Warsaw University of Life Sciences-SGGW, Agriculture, 66, 89-98.

[17] Stempski, W., Jabłoński, K., \& Wegner, J. (2010). Effect of the edge geometry in a cutting chain on the saw vibration level. Acta Scientiarum Polonorum, 9(1), 25-33.

[18] Stempski, W., Jabłoński, K., \& Wegner, J. (2010). Relations between top-plate filling angle values of cutting chains and chainsaw vibration levels. Acta Scientiarum Polonorum, 9(2), 31-39.

[19] Maciak, A. \& Gendek, A. (2007). Effect of cutting with the chainsaw with two pairs of cutting link per section. Annals of Warsaw University of Life Sciences-SGGW, Agriculture, 50, 59-63.

[20] Rukat, W. \& Jakubek, B. (2017). The influence of the cutting tooth design and wear of a saw chain on the vibration level of a chainsaw. Vibration in Physical Systems, 28(009), 1-8.

[21] Takimoto, Y., Sukenaga, T., Fujii, Y., Gotou, J., \& Sasaki, I. (1984). On the characteristics of Twin-chainsaw-vibration. BULLETIN OF THE TOKYO UNIVERSITY FORESTS, 56, 178-189.

[22] Skarżyński, J. \& Pietrkiewicz, P. (2013). Effect of chain saw pitch on vibration level on the internal combustion chain saw handles during cross cutting of wood. Annals of Warsaw University of Life Sciences-SGGW, Agriculture, 61, 57-63.

[23] Skarżyński, J. \& Wójcik, K. (2008). Timber hardness impact on the level of vibrations I.C.E.-powered sawing machine grips during cutting. Inżynieria Rolnicza, 99, 345-351 (in Polish).
[24] Skarżyński, J. (2007). Influence of wood diameter on the level of vibrations on chainsaw handles during wood cutting. Technika Rolnicza Ogrodnicza Leśna, 5.

[25] Wójcik, K., Skarżyński, J., \& Szałek, M. (2009). The influence of different pine wood diameters on Stihl E180 electric chainsaw vibration during cross-cutting. Zeszyty Problemowe Postęów Nauk Rolniczych, 543, 395-408.

[26] Malinowska-Borowska, J., Harazin, B., \& Zieliński, G. (2011). The influence of wood hardness and logging operation on coupling forces exerted by lumberjacks during wood harvesting. International Journal of Industrial Ergonomics, 41, 546-550. https://doi.org/10.1016/j.ergon.2011.06.001

[27] Rottensteiner, C., Tsioras, P., \& Stampfer, K. (2012). Wood density impact on Hand-arm vibration. Croatian Journal of forest Engineering: Journal of Theory and Application of Forestry engineering, 33(2), 303-312.

[28] Gendek, A., Aniszewska, M., Nurek, T., \& Moskalik, T. (2018). State of training and equipment of chainsaw operators employed for timber harvesting in Polish forests. Sylwan, 162(2), 118-126 (in Polish).

[29] Calcante, A., Facchinetti, D., \& Pessina, D. (2018). Analysis of Hazardous Emissions of Hand-Operated Forestry Machines Fuelled with Standard Mix or Alkylate Gasoline. Croatian Journal of Forest Engineering, 39(1), 109-116.

[30] Neri, F., Foderi, C., Laschi, A., Fabiano, F., Cambi, M., Sciarra, G., Aprea, M. C., Cenni, A., \& Marchi, E. (2016). Determining exhaust fumes exposure in chainsaw operators. Environmental Pollution, 218, 1162-1169. https://doi.org/10.1016/j.envpol.2016.08.070

[31] Lijewski, P., Fuc, P., Dobrzyński, M., \& Markiewicz, F. (2017). Exhaust emissions from small engines in handheld devices. MATEC Web of Conferences, VII International Congress on Combustion Engines, 188(00016), 1-5. https://doi.org/10.1051/matecconf/201711800016

[32] Dimou, V., Anezakis, V. D., Demertzis, K., \& Iliadis, L. (2017). Comparative analysis of exhaust emissions caused by chainsaws with soft computing and statistical approaches. International Journal of Environmental Science and Technology, 15(3), 1-12. https://doi.org/10.1007/s13762-017-1555-0

[33] Magnusson, R., Nilsson, C., Andersson, K., Andersson, B., Rannug, U., \& Östman, C. (2000). Effect of Gasoline and Lubricant on Emissions and Mutagenicity of Particles and Semivolatiles in Chain Saw Exhaust. Environmental Science and Technology, 34(14), 2918-2924. https://doi.org/10.1021/es9912022

[34] Rozporządzenie Ministra Pracy i Polityki Społecznej z dnia 6 czerwca 2014 roku w sprawie najwyższych dopuszczalnych stężeń i natężeń czynników szkodliwych dla zdrowia w środowisku pracy. Dz.U. z 2014 r. poz. 817.

[35] Skorupski, M. \& Wierzbicka, A. (2013). Vadmecum selected zoonoses in the forest environment. Katedra Łowiectwa i Ochrony Lasu, Wydzial Leśny Uniwersytetu Przyrodniczego w Poznaniu. Poznan.

[36] Dobracki, W. (1995). Zoonoses-truth and myths. Medycyna weterynaryjna, 51(4), 187-190.

[37] Gliński, Z. \& Kostro, K. (2009). Non-domestic animals as a source of zoonotic diseases-zoonotic viral agents. Życie weterynaryjne, 84(7), 536-541.

[38] Su, A. T., Maeda, S., Fukumoto, J., Miyia, N., Isahak, M., Yoshioka, A., Nakajima, R., Bulgiba, A., \& Miyashita, K, (2014). A cross sectional study on hand-arm vibration syndrome among a group of tree fellers in a tropical environment. Industrial Health, 52, 367-376. https://doi.org/10.2486/indhealth.2013-0137

[39] Pakulska, D., Soćko, R., \& Szymczak, W. (2017). Wood dust-inhalable fraction Documentation of proposed values of occupational exposure limits. Podstawy $i$ metody oceny środowiska pracy, 93(3), 17-93. 
https://doi.org/10.5604/01.3001.0010.4272

[40] Hejnowicz, Z. (1980). Anatomy and histogenesis of vascular plants. PWN, W-wa (1980); ISBN 83-01-00420-7, 794-795.

[41] Malinowski, E. (1973). Plant anatomy. PWN, Warsaw, 190191 (in Polish).

[42] Lis, A. \& Lis, P. (2013). Characteristics of the strength of wood as its basic mechanical properties. Wydawnictwo Politechniki Czestochowskiej, Zeszyty Naukowe Politechniki Częstochowskiej, Budownictwo, 19(169), 77-86.

[43] Kimbar, R. (2011). Wood defects. Oficyna Wydawnicza Oikos, ISBN 978-83-933251-1-5 SN.

[44] ISO 7505:1986 Forestry machinery-Chain sawMeasurement of hand transmitted vibration.

[45] ISO 22867:2011 Forestry and gardening machineryVibration test code for portable hand-held machines with internal combustion engine-Vibration at the handle.

[46] EN ISO 5349-1Mechanical Vibration-Measurement and Evaluation of Human Exposure to Hand-Transmitted Vibration-Part 1: General Requirements.

[47] EN ISO 5349-2 Mechanical Vibration-Measurement and Evaluation of Human Exposure to Hand-Transmitted Vibration-Part 2: Practical Guidance for Measurement at the Workplace.

[48] ISO 22868:2011 Forestry and gardening machinery-Noise test code for portable hand-held machines with internal combustion engine-Engineering method.

[49] Directive 2001/44/EC of the European Parliament and the Council -on the minimum health and safety requirements regarding the exposure of workers to the risks arising from physical agents (vibration) (sixteenth individual Directive within the meaning of Article 16(1) of Directive 89/391/EEC).

[50] Grzywiński, W., Wandycz, A., Tomczak, A., \& Jelonek. T. (2016). The prevalence of self-reported musculoskeletal symptoms among loggers in Poland. International Journal of Industrial Ergonomics, 52, 12-17. https://doi.org/10.1016/j.ergon.2015.07.003

[51] Malinowska-Borowska, J., Socholik, V., \& Harazin, B. (2012). The Health Condition of Forest Workers Exposed to Noise and Vibration Produced by Chainsaws. Medycyna Pracy, 63(1), 19-29.

[52] Nowacka, W. Ł. \& Moskalik, T. (2013). The negative effects of working in forestry with special focus on timber harvesting. Forestry Letters, 105, 85-93.

[53] Su, A. T., Maeda, S., Fukumoto, J., Miyia, N., Isahak, M., Yoshioka, A., Nakajima, R., Bulgiba, A., \& Miyashita, K. (2014). A cross sectional study on hand-arm vibration syndrome among a group of tree fellers in a tropical environment. Industrial Health, 52, 367-376.

https://doi.org/10.2486/indhealth.2013-0137

\section{Contact information:}

Wojciech RUKAT, MSc

(Corresponding author)

Poznan University of Technology, Institute of Applied Mechanics Jana Pawla II 24 St., 61-139 Poznan, POLAND

E-mail:wojciech.rukat@put.poznan.pl

\section{Bartosz JAKUBEK, MSc.}

Poznan University of Technology, Institute of Applied Mechanics, Jana Pawla II 24 St., 61-139 Poznan, POLAND

E-mail: bartosz.jakubek@put.poznan.pl

Roman BARCZEWSKI, DSc DEng

Poznan University of Technology, Institute of Applied Mechanics, Jana Pawla II 24 St., 61-139 Poznan, POLAND

E-mail: roman.barczewski@put.poznan.pl

Mateusz WRÓBEL, MSc.

Poznan University of Technology, Institute of Applied Mechanics, Jana Pawla II 24 St., 61-139 Poznan, POLAND

E-mail: mateusz.wrobel@put.poznan.pl 